\title{
Scrambling and Reference in German
}

\author{
Jürgen Lenerz \\ University of Cologne \\ juergen.lenerz@uni-koeln.de
}

Although the linear order of arguments (and adverbials) in German is relatively free, it underlies certain restrictions; these don't apply to the so-called unmarked order for arguments (Lenerz 1977) and adverbials (Frey/Pittner 1998). It is a common assumption to take the unmarked order as basic and derive all other orders from it by scrambling, whatever its specific characteristics may be (cf., amongst others, Haider/Rosengren 1998). The observable restrictions obtaining for some linear ordering may then be considered as constraints on a movement operation (scrambling). Some well known restrictions are given in (1), exemplified by the linear order of indirect (IO) and direct object (DO). In the examples (2) - (4), the focussed NP is the questioned argument, e.g. $\mathrm{Q}: \mathrm{IO}$ in (2):

(1) a. $\quad[ \pm$ def $\mathrm{IO}]>[ \pm \mathrm{def} \mathrm{DO}]$ : “unmarked order”, regardless of focus position (cf. (2a), (3a), (4a)).

b. $\quad[+\operatorname{def} \mathrm{DO}]>[\mathrm{IO}]_{\mathrm{F}}$ : scrambling of [+def, $\left.-\mathrm{F}\right]$ is ok (cf. (2b)).

c. $\quad *[ \pm \text { def } \mathrm{DO}]_{\mathrm{F}}>\mathrm{IO}=$ Don't scramble focus ! (cf. (3))

d. $\quad *[-\operatorname{def} \mathrm{DO}]>[\mathrm{IO}]_{\mathrm{F}}=$ Don't scramble (existential) indefinites ! (cf. (4))

(2) Wem hast du das Buch gegeben?

$\mathrm{Q}: \mathrm{IO}$

'Whom did you give the book?'

a. Ich habe [dem/einem StuDENten $]_{\mathrm{F}}$ das /ein Buch gegeben.

$$
I \text { have the / a student the /a l l } \begin{aligned}
& {\left[ \pm \text { def. } \mathrm{IO}_{\mathrm{F}}>[ \pm \text { def. DO }\right.} \\
& \text { ("unmarken } \\
& \text { ("unmarder") }
\end{aligned}
$$

b. Ich habe das Buch [dem/einem StuDENten $]_{\mathrm{F}}$ gegeben

$$
[+ \text { def. DO }]>[ \pm \text { def. } \mathrm{IO}]_{\mathrm{F}}
$$

I have the book the / a student given

(scrambled [+def DO,-F] is o.k.)

'I gave the book to the student.'

(3) Was hast du dem Studenten gegeben? Q : DO

'What did you give to the student?'

a. Ich habe dem Studenten [das $\mathrm{BUCH}]_{\mathrm{F}}$ gegeben.

I have the student the book given ( "unmarked order")

b. $\quad *$ ?Ich habe $[\text { das } \mathrm{BUCH}]_{\mathrm{F}}$ dem Studenten gegeben.

$*[+ \text { def. DO }]_{\mathrm{F}}>[+$ def. IO $]$

I have the book the student given (*scrambled focus)

'I gave the student the book.' 
'Whom did you give a book?'

a. Ich habe [dem/einem StuDENten $]_{\mathrm{F}}$ ein Buch gegeben

$$
\text { I have the / a student a book given }]_{\mathrm{F}}>\text { [-def. DO] }
$$

b. $\quad *$ Ich habe ein Buch [dem StuDENten $]_{\mathrm{F}}$ gegeben.

I have a book the student given $*[$-def. DO $]>[+ \text { def. } \mathrm{IO}]_{\mathrm{F}}$

(*scrambled indefinite NP)

c. $\quad *$ Ich habe ein Buch [einem StuDENten $]_{\mathrm{F}}$ gegeben.

$$
\begin{aligned}
& \text { I have a book a student given } \\
& * \text { [-def. DO] }>\text { [-def IO }]_{\mathrm{F}}
\end{aligned}
$$

'I gave a book to the student.'

(*scrambled indefinite NP)

As the standard examples in (2)-(4) show, IO > DO is assumed to be the unmarked order for most verbs taking two objects; here, no specific restrictions apply: every distribution of definite or indefinite NP and focus is possible for that order, cf. (2a), (3a), (4a). Scrambling a definite DO to the left of a focussed IO gives a possible order, too, cf. (2b). If, however, the scrambled DO is a focussed NP, it must not be scrambled in front of an IO, cf. (3b). Thus, (1c) "Don't scramble focus!" is a crucial restriction on scrambling in German. It may be accounted for by the interaction of focus placement, focus projection and, possibly, the proper assignment of prosodic features (cf., amongst others, Büring 1997, 2001, von Heusinger 1999). Thus, this restriction may find a plausible functional explanation ensuring the proper interpretation of a sentence wrt background-focus structure and the formal means for its expression, i.e. linear order and prosodic prominence.

There is, however, an additional restriction, for which, to my knowledge, so far no explanation has been proposed. As (4b), (4c) show, an indefinite DO should not be scrambled across an IO, even if the condition (1c) on focus-scrambling is not violated. Examples (4b), (4c) suggest that scrambling of an indefinite DO is not possible in general. As (5a), however, shows, the scrambled DO einen obszönen Witz ('an obscene joke') may be scrambled under certain conditions:

(5) Wem erzählt Peter einen obszönen Witz? „Whom does Peter tell an obscene joke?“

a. $\quad$ Peter erzählt einen obszönen Witz immer einem Schulfreund. (generic)

Peter tells an obscene joke always a-DAT schoolmate

'Peter tells an obscene joke always to a schoolmate.'

As far as is known, in this case the scrambling must be to a position outside the VP, as indicated by the temporal adverbial immer ('always') which is assumed to indicate the left boundary of VP. In this case, the scrambled DO may receive a non-existential, generic reading. Thus, the proper constraint on scrambling is assumed to be (1d) "Don't scramble existential indefinites!”. Generic indefinites, however, may be scrambled (provided that the sentence itself allows for a generic interpretation). 
It should be pointed out, however, that this restriction is still too weak: Scrambling across a subject (6a) is still not possible, whereas the (generic) subject itself may be scrambled as in (6b).

(6) a. *weil einen obszönen Witz immer Peter einem Schulfreund erzählt. since an obscene joke always Peter a-DAT schoolmate tells

b. $\quad$ weil obszöne Witze immer an Herrenabenden erzählt werden. since obscene jokes always on boy-nights told become 'Since obscene jokes will always be told on boys' nights.'

Thus, scrambling seems to be also sensitive to the syntactic hierarchy of arguments. Possibly, the restriction as stated above in (1d) is also too strong: In some cases the scrambling of existential indefinites seems to me to be possible, as will be shown below, cf. (14b).

In the following, I will try to present the outlines of a possible explanation for the restriction (1d), based on a proposal governing the proper referential interpretation of indefinite NPs.

Before doing so, however, let me point out some crucial shortcomings of some current proposals.

It has been assumed that syntactic structure shows a bi-partition parallel to the bipartition of a formula of standard predicate logic (cf. Diesing 1990 and much consecutive discussion). A quantified logical formula like

$$
\forall \mathrm{x}(\operatorname{man}(\mathrm{x})) \exists \mathrm{y}(\text { woman }(\mathrm{y}) \wedge \text { love }(\mathrm{x}, \mathrm{y})) \text { (every man loves a woman) }
$$

may be split into a restrictive clause defining the domain of the universal quantifier ( $\forall \mathrm{x}$ $($ man $(\mathrm{x})))$ and the so-called nuclear scope $(\exists \mathrm{y}$ (woman $(\mathrm{x}) \wedge$ love $(\mathrm{x}, \mathrm{y})))$ containing the assertion being made of the individual(s) in the restrictive clause.

$$
\begin{aligned}
& \text { a. } \quad \forall \mathrm{x}(\operatorname{man}(\mathrm{x})) \quad\|\| \exists \mathrm{y}(\text { woman }(\mathrm{y}) \wedge \text { love }(\mathrm{x}, \mathrm{y}))(\text { every man loves } a \\
& \text { restrictive clause |||| nuclear scope } \\
& \text { (CP) }{ }_{\mathrm{IP}}\left[\ldots . . \text { [ Sadv }\|\| \| \quad{ }_{\mathrm{VP}}[\ldots . .]\right] \\
& \forall \text {, GEN }\|\| \| \quad \exists
\end{aligned}
$$

So, some authors have assumed that the part of a sentence before the sentence adverbial corresponds to the restrictive clause, the part following the adverbial representing the nuclear scope. The readings in $(8 \mathrm{a}, \mathrm{b})$ are thus assumed to follow from a syntactic bipartition corresponding to the bi-partition of the formula of standard predicate logic.

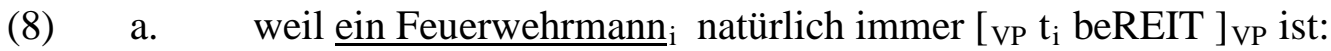

because a fireman naturally always generic reading 'because a fireman is of course always ready' 
b. weil natürlich immer [vp ein Feuerwehrmann beREIT $]_{\mathrm{VP}}$ ist:

because naturally always a fireman existential reading
'because there is of course always a fireman ready'

Notice, however, that there is no reason why the syntactic structure should correspond to a fairly arbitrary partition of a formula of standard predicate logic as the latter was not devised to reflect syntactic structure at all. Consequently, a proper semantic structure giving us a compositional semantic interpretation of sentences like (8a) or (8b) will deviate from the fairly simple format of (7), as a more detailed representation in categorial grammar would show immediately. Such representations are indeed based on the syntactic structure which is taken to be independent of semantic translations like (7) and exist prior to them.

For this reason, I tried to provide an independent motivation for the syntactic bipartition (Lenerz 2001). I assumed that the part preceding the sentence adverbial (thus: outside the VP) be interpreted as the part of the sentence containing background information (B-part) whereas the VP proper be the part containing the focussed elements (F-part), i.e. the new information being asserted to hold true of the B-part.

$$
\begin{aligned}
& \text { b. (CP) }{ }_{\mathrm{IP}}\left[\ldots . \text { [ Sadv } \quad\|\| \mid{ }_{\mathrm{VP}}[\ldots .]\right] \\
& \text { B-part } \quad\|\| \quad \text { F-Part (background vs. focus) } \\
& b \text {-determined reference } \quad\|\| \mid \text { isc-dependent reference } \\
& \text { (isc = immediate sentence constituent) }
\end{aligned}
$$

This provided a first step towards an explanation of the scrambling restriction (1d):

The reference of the elements in the B-part is plausibly established by background information (b-determined reference). Thus, indefinites in the B-part should be interpreted as given or known in their reference, hence as generic. On the other hand, the referential expressions in the F-part represent new information. Their reference is, however, restricted by other referential expressions in the sentence as a whole, i.e. dependent on immediate sentence constituents (isc-dependent reference). Although I think that this proposal was basically on the right track, it has two shortcomings: First, in the light of recent work of Frey (2000) the characterization of the bi-partition into "Bpart" and "F-part" is misguided. Rather, as Frey (2000) points out, the sentence adverbials (or, more precisely, possibly the temporal adverbials) marking the left boundary of the VP proper distinguish between a field containing a (number of) topic phrase(s) and the VP proper containing only the comment (cf. also Rizzi 1997), cf. (12) below.

Second, the restriction of the reference of isc-dependent expressions seems to me far more general than I assumed in Lenerz (2001).

Let us therefore take a closer look at the referential properties of indefinite NPs. Indefinite determiners may be interpreted as choice functions which pick an arbitrary referent out of a "reference set" which is characterized by the noun (cf. von Heusinger 1997). The proper choice of the "reference set" of a given NP itself is dependent on (restricted by) the reference of expressions which c-command the NP in D-structure ( $\mathrm{X} \leftarrow$ ref.dep. $\leftarrow \mathrm{Y}=\mathrm{Y}$ is referentially dependent on / referentially restricted by $\mathrm{X}$ ); hence the 'unmarked order' of arguments $(\mathrm{SU}<\mathrm{IO}<\mathrm{DO}<\mathrm{V}$ ) which does not underlie 
any restrictions w.r.t. context / information structure / referential status: SU $\leftarrow$ ref.dep $\leftarrow$ IO $\leftarrow$ ref.dep. $\leftarrow$ DO

So, in (9) the indefinite NP ein Buch does not refer to any arbitrary element of the set of books but is in its reference restricted by at least the c-commanding referential expressions der Professor and dem Studenten. A rough rendering of its interpretation may be given as $(9 \mathrm{~b})$.

(9) a. weil (der) Professor (dem) Studenten gestern ein Buch gegeben hat. since the professor the-DAT student yesterday a-ACC book given has 'Since the professor gave the student a book.'

b. $\quad$ ein Buch $=[\mid$ an arbitrary element of the set of books which were available yesterday to the professor and the student []

Here, 'available' is a rather vague term synonymous with what I dubbed dependent or restricted further above.

Similarly, the reference of the indefinite NP einem Studenten in (9c) may be paraphrased as (9d).

(9) c. weil der Professor gestern einem Studenten das Buch gegeben hat. since the professor yesterday a-DAT student the-ACC book given has 'Since the professor gave a student the book.'

d. $\quad$ einem Studenten $=[\mid$ an arbitrary element of the set of students which were available yesterday to the professor []

The essential idea now is that an indefinite NP looses its referential dependency if it is scrambled. Different versions of this idea come to mind, as W. Frey (p. c.) pointed out to me: In a strong version, a scrambled NP looses its referential dependency altogether. In this view, a scrambled NP has to be interpreted as referring to an arbitrary element of the non-restricted set of elements defined by the noun. A weaker version would hold that a scrambled NP looses only the referential dependency which extends from those referential expressions across which it has been scrambled. I have not been able to decide empirically which version is correct. One observation may be in favor of the weak version: Scrambling across an object NP (10a) seems to result in a weaker deviation than scrambling across an object and a subject (10b):
a. $\quad$ ?*weil der Professor ein
Buch dem
Studenten gegeben hat. since the professor a-ACC book the-DAT student given has 'since the professor gave a book (to) the student.'
b. *weil ein Buch der Professor dem Studenten gegeben hat Since a-ACC book the professor the-DAT student given has

Similar grades of ungrammaticality may also be observed with scrambling across adverbials. This is an area requiring some further investigation. It follows, however, from both versions that the scrambling of an indefinite NP results in a loss of its proper referential dependency. Thus, a proper interpretation of the sentence will no longer be possible if the sentence consists of a specific predication made of its subject NP. So, in the strong version of the principle of referential dependency, an interpretation of an ungrammatical sentence like (10b) will be something like (11), certainly a paraphrase of an utterance which does not make any sense. 
(11) *it is true for [| any arbitrary book |] that a specific professor gave it to a specific student at a specific time.

So far, a concept of the referential dependency of indefinite NPs will enable us to account for the ungrammaticality of scrambled NPs if they are to be interpreted as existential.

In order to account for the generic interpretation of (at least some) scrambled indefinites, we will have to take a closer look at the topological and hierarchical structure of German sentences. As Rizzi (1997), Fry (2000), Frey/Pittner (1998), Meinunger (2000) have pointed out, there are several functional projections above VP, giving us two or three "fields" for scrambling. Details of the differences between the various proposals aside, it seems necessary to assume at least a number of topic phrases (TopP) above VP, constituting a field for scrambling which may also contain at most one Focus Phrase (FocP). Also, there is, of course, still the VP proper which is a field for (VP-internal) scrambling. Following Frey (2000), one may in addition assume scrambling to a field between the sentence adverbial and a temporal adverbial at the left periphery of the VP.

$$
\begin{aligned}
& \text { (at least) three scrambling- "fields": } \\
& {\left[\text { CP } \text { ? } \left[\operatorname{TopP}^{*} \text { (FocP) TopP }{ }^{*} \text { ? }[\text { Sadv ... ? ? TempAdv vp[(SU) ... ] ] ] ] }\right.\right.}
\end{aligned}
$$

I shall not be concerned with a detailed analysis; for valuable observations and their theoretical implications cf. Frey (2000). For my present purpose, it suffices to point out, following Frey (2000), that the Topic Phrases in (12) are to be interpreted not as 'familiarity'-topics but as 'aboutness'-topics. This is immediately made clear by the example (13), taken from Frey (2000). Here, the context given in (13) provides for an 'aboutness'-interpretation of the NP Otto. The following sentence (13a) complies with this, as Otto is in an ('aboutness')-topic position. (13b) is not a proper successor for (13) since Otto in (13b) is not an 'aboutness'-topic.

(13) Ich erzähl dir mal was von Otto. ,Well, I’ll tell you something about Otto.'

a. Nächstes Jahr wird Otto wahrscheinlich seine Kollegin heiraten. next year will Otto probably his colleague(fem.) marry 'Next Year, Otto will probably marry his colleague.'

\# Nächstes Jahr wird wahrscheinlich Otto seine Kollegin heiraten. next year will probably Otto his colleague marry

From the assumption that we are dealing with 'aboutness'-topics, it follows immediately that non-referring expressions like keiner ('nobody'), not being 'aboutness'-topics, cannot appear in this position.

If this is basically correct, as I assume, the possibility of a generic interpretation of NPs which have been scrambled to a topic-position follows: If an indefinite NP is scrambled to a topic-position, it becomes an 'aboutness'-topic, the rest of the sentence being a comment on this topic. In other words, a topic-comment structure establishes a kind of secondary prediction. The comment itself, containing the primary predication (subject-predicate, possibly represented inside the VP) has to make sense w.r.t. the topic it is about. Thus, a scrambled generic NP requires, of course, a generic comment, as in (14a). 
(14) a. weil Väter natürlich oft mit ihren Kindern spielen. (GEN) since fathers naturally often with their children play 'Since fathers do of course often play with their children.'

If this analysis is correct it does not follow however that a NP which is scrambled to a topic-position must be interpreted as generic. Thus, given a proper specific comment, the scrambled NP should also be interpretable with a specific existential reference, as (14b), I believe, shows.

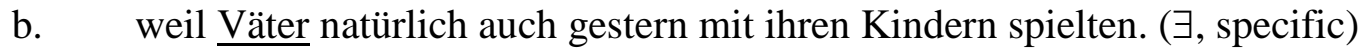
Since fathers naturally also yesterday with their children played 'Since also yesterday fathers played with their children.'

Notice that in my present analysis this is predicted whereas with a bi-partition analysis along the lines of (7a) a generic reading is stipulated, and an existential reading for a scrambled NP is ruled out. The same holds for my previous analysis (7b) since the reference of a scrambled NP in the B-part of the sentence (referring to background knowledge) has to be taken to be established, hence an existential reading should not be possible. I conclude, thus, that the restriction on the scrambling of indefinites as given above is wrong. The correct restriction seems to be (15):

(15) a. don't scramble indefinites inside the VP (=this follows from referential dependency)

b. indefinites which are scrambled to the topic-position are only allowed if they can be interpreted as referentially independent from referential expressions which they c-command in the scrambling position.

Both parts of this condition follow from a proper theory of referential dependency together with a proper theory of topic-comment-structure and its interpretation. Details of both theories will of course have to be worked out.

In the rest of this paper, I will discuss some ramifications and some possible consequences of a theory of referential dependency.

As pointed out above, scrambling across a subject is ungrammatical in most cases, cf. (16).

$$
\begin{aligned}
& \text { *weil Eisbären } \\
& \text { Since polar bears(ACC) naturally Paul yesterday took-pictures-of }
\end{aligned}
$$

This statement has to be relativized, however, given examples like (17).

weil Eisbären natürlich alle mögen / niemand mag. (GEN)

Since polar bears(ACC) naturally all like / nobody likes

'Since, naturally, everybody / nobody likes polar bears.'

Here a subject NP with a universal quantifier (alle 'everybody') or a negated existential quantifier (niemand, 'nobody') does not block scrambling of the indefinite NP Eisbären ('polar bears'). It cannot be the generic quality of the subject NP as such 
which allows for scrambling, as (18) shows, where the generic indefinite NP Eisbären ('polar bears') has been scrambled across the generic subject NP ein Eskimo ('an Eskimo’).

*weil Eisbären natürlich ein Eskimo gerne jagt. since polar bears naturally an Eskimo gladly hunts 'since an Eskimo likes to hunt polar bears.'

The facts are far from clear especially as one tends to utter sentences like (17) or (18) with a bridge accent, stressing the scrambled NP (Eisbären) as well as the subject NP (alle, keiner, ein Eskimo). This specific intonation pattern seems to 'rescue' the sentences. (For details of a proper analysis of bridge accent structures cf. Büring 1997, among others). With normal sentence intonation, however, (18) seems to me to be ungrammatical. What would follow along the lines of explanation which I suggested is the following:

While (17) is a possible topic-comment structure, (18) is not. In (17), a kind of 'secondary predication' is made of polar bears in general: Everybody/nobody likes them. In (18) however, the comment on the topic phrase Eisbären does not seem reasonable: It does not make much sense to assert of polar bears that in general it is true that any (generic) Eskimo has the property of liking to hunt them. So, again, an explanation for the constraint to scramble across referentially restricted subjects (as in (18), as opposed to (17) with subject NPs which are not restricted referentially) relies on a proper theory of referential dependency and a proper theory of topic-comment structure and its interpretation.

Another observation concerns the order of arguments in the topic field. As Meinunger (2000) points out, Rizzi's (1997) proposal of a series of topic phrases wedged in between the functional projections CP on the left and possibly IP or some part of it on the right, cf. (12), has to be revised: Meinunger analyzes the Topic Phrases as Agreement Phrases. Their unmarked hierarchical order seems to be the same as inside the VP, as $(19 a, b, c)$ show.
a. weil Paul seiner Freundin Schmuck natürlich gerne schenkt.
since Paul his-DAT girl-friend jewelleyr(ACC) naturally gladly donates 'Since Paul likes to give his girl friend jewellery'
b. *weil Paul Schmuck seiner Freundin natürlich gerne schenkt since Paul jewellery(ACC) his-DAT girl-friend naturally gladly donates
c. *weil Schmuck Paul seiner Freundin natürlich gerne schenkt. Since jewellery(ACC) Paul his-DAT girl-friend naturally gladly donates

All the arguments in these sentences are scrambled across the sentence adverbial natürlich ('naturally'), thus above the VP-projection. If their ordering violates the unmarked order $\mathrm{SV}>\mathrm{IO}>\mathrm{DO}$, as in (19b,c), the sentence is ungrammatical. If this is true, it indicates strongly that referential dependency does not only apply inside the VP but inside the whole 'middle field' of German sentences, i.e. to the whole part of the sentence below the CP.

The initial field, however, does not seem to participate in the overall relationship of c-commanding referential dependency. Thus, a NP in SpecCP retains its referential dependency from its original position. Hence, movement to SpecCP does not have to obey the restrictions which hold for scrambling; consequently, any NP (or any other 
maximal projection) may be placed in the initial field no matter where its source in the base structure is. This can be shown quite clearly if we consider possessive phrases, a good example of referential dependency. A possessive pronoun may refer to a ccommanding NP only in the unmarked order (20a):
a. Gestern hat tatsächlich (der) $\quad$ Peter $_{\mathrm{i}}$ seinen $_{\mathrm{i}} \quad$ Bruder gelobt. praised yesterday has actually (the-NOM) Peter ${ }_{i}$ his ${ }_{i}$-ACC brother
'Yesterday, Peter actually praised his brother.'
b. * Gestern hat tatsächlich seinen ${ }_{\mathrm{i}}$ Bruder (der) Peter ${ }_{\mathrm{i}}$ gelobt. yesterday has actually his ${ }_{i}$-ACC brother the-NOM Peter praised
c. *Gestern hat seinen i Bruder tatsächlich der Peter i gelobt. Yesterday has his ${ }_{i}$-ACC brother actually the-NOM Peter ${ }_{i}$ praised $^{-}$
d. $\quad$ Seinen $_{\mathrm{i}}$ Bruder hat (der) Peter ${ }_{\mathrm{i}}$ gestern gelobt.
His ${ }_{i}$-ACC brother has the-NOM Peter ${ }_{i}$ yesterday praised

If the possessive phrase is scrambled, as in (20b,c), it looses its co-reference with a NP across which it has been scrambled. If, however, the possessive phrase is moved to the initial position as in (20d), it retains the possibility of co-reference with the subject NP across which it has been moved. (Non-co-referential readings of the possessive pronoun are possible throughout since they do not show the kind of (co)-referential dependency requiring the corresponding c-command relations.)

A closer look reveals, however, that the conditions are a little more complicated if we consider the interaction with adverbials. If my judgement is correct, then movement of an object NP to the sentence initial position seems only possible if the subject has been scrambled from its VP-internal position, as the examples in (21a-c) show.
a. Eisbären hat Paul natürlich immer geliebt. polar bears(ACC) has Paul naturally always loved 'Polar bears, Paul always loved them'
b. Eisbären hat natürlich Paul immer geliebt. polar bears(ACC) has naturally Paul always loved
c. *Eisbären hat natürlich immer Paul geliebt. polar bears(ACC) has naturally always Paul loved

The case is different if the subject is moved to SpecCP as in (22). In this case the object Eisbären 'polar bears' may either remain inside the VP (22a) or be scrambled to a topic position (22b).
b. Paul hat natürlich immer Eisbären geliebt. Paul has naturally always polar bears (ACC) loved
a. Paul hat Eisbären natürlich immer geliebt.
Paul has polar bears(ACC) naturally always loved 'Paul has of course always loved polar bears.'

Still, both sentences seem to have a slightly different interpretation. What comes to mind in the present discussion is the idea that here, too, referential dependency plays a role. For the cases in (21), my explanation would be as follows: Let us assume a 
referential dependency between the subject and the temporal adverbial. If the definite subject Paul stays in its base position inside the VP, as in (21a), the temporal adverbial immer ('always') is not restricted referentially. Thus, (21a) would have the interpretation that for all times in the universe it be true that the specific individual Paul loves polar bears, clearly not a reasonable assertion, given that individuals like Paul only live for a specific period of time. In (21b), however, the temporal adverbial is referentially dependent from the scrambled subject which c-commands it from its topic position. In this case, immer ('always') may only refer to all times available to Paul, as it were, giving the intended interpretation. Similar considerations will apply to the slight difference in meaning between (22a) and (22b). Whatever the details of the analysis will turn out to be, what (21) and (22) show us is that there exists some paradoxical kind of interaction between scrambling and movement to SpecCP which has to be investigated in more detail: A temporal adverbial seems to be referentially dependent from a subject in SpecCP. This looks as if movement to SpecCP presupposes scrambling to a topic position in which the required referential dependency is established. On the other hand, an object in SpecCP seems to retain its referential dependency from its base position.

As regards possessive phrases, they also show that it is necessary to assume such an interaction between scrambling and movement to the initial position. As (23a) shows, scrambling of the definite IO dem Otto ('the-DAT Otto') to a topic position enables us to interpret the subject NP sein Vater ('his father') with a co-referent possessive pronoun, as indicated by the indices. This is not possible for (23b). Here, the subject is scrambled to a topic position in which its possessive pronoun is not c-commanded by the co-referential NP Otto, hence cannot be interpreted as referentially dependent. (Again, as in (20), non-co-referential readings are possible.)

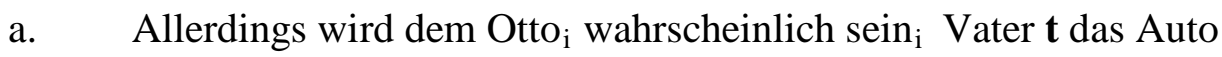

ausleihen.

Indeed will the-DAT Otto ${ }_{i}$ probably his father the car lend 'Indeed, Otto's father will probably lend him the car.'

b. $\quad *$ Allerdings wird $\operatorname{sein}_{\mathrm{i}}$ Vater wahrscheinlich $\mathbf{t}$ dem Otto $_{\mathrm{i}}$ das Auto ausleihen. Indeed will his ${ }_{i}$ father probably the-DAT-Otto $i$ the car lend.

a. $\quad \operatorname{Sein}_{\mathrm{i}}$ Vater wird dem Otto $_{\mathrm{i}}$ wahrscheinlich t das Auto ausleihen. His $_{i}$ father will the-DAT Otto ${ }_{i}$ probably the car lend 'Probably, Otto's father will lend him the car.'

b. * $\quad$ Sein $_{\mathrm{i}}$ Vater wird wahrscheinlich t dem Otto $\mathrm{i}_{\mathrm{i}}$ das Auto ausleihen. His $_{i}$ father will probably the-DAT Otto ${ }_{i}$ the car lend

Fronting of the possessive phrase in (24a) is possible with the co-referential reading. Given the scenario I assumed so far, this is explained if we assume the structure indicated by the trace in the VP-internal subject position, i.e. if we assume an underlying structure with the IO scrambled to a topic position. (24b), however, is ungrammatical with a co-referential reading. This would be explained if we assume an underlying structure in which the fronted phrase originates in the position indicated by the trace. 
Many puzzles remain. What the preceding discussion of but a few cases of referential dependency, however, shows, to my mind, is that the area of application of the concept of referential dependency is quite diversified and the crucial facts are as yet not understood very well at all. Furthermore, it seems to me, the very general concept of referential dependency, if correct, may also be relied upon to derive the property and position of personal pronouns and other referential expressions. Hence, binding theory and a proper theory of the interaction of quantifiers may eventually turn out to follow from a general theory of referential dependency yet to be elaborated.

\section{References:}

Büring, Daniel (1997). The Meaning of Topic and Focus - The 59 ${ }^{\text {th }}$ Street Bridge Accent. London: Routledge.

Büring, Daniel. forthcoming. Let's Phrase It! — Focus, Word Order, and Prosodic Phrasing in German Double Object Constructions. Competition in Syntax, edited by Gereon Müller and Wolfgang Sternefeld, 101-137. Amsterdam: Benjamins.

Double Object Constructions. In: Müller, Gereon/Sternefeld Wolfgang (eds.) (2001) Competition in Syntax, 69-105.

Diesing. Molly (1990). The Syntactic Roots of Semantic Partition. PhD. Diss. U of Mass. Amherst.

Frey, Werner (2000). Über die syntaktische Position der Satztopiks im Deutschen. In: ZAS Papers in Linguistics 20, 137-172.

Frey, Werner/Pittner, Karin (1998). Zur Positionierung der Adverbiale im deutschen Mittelfeld. In: Linguistische Berichte 176, 489-534.

Haider, Hubert/Rosengren, Inger(1998). Scrambling. Universität Lund (=Sprache und Pragmatik. Arbeitsberichte 49).

Heusinger, Klaus von (1997). Salienz und Referenz: Der Epsilonoperator in der Semantik der Nominalphrase und anaphorischer Pronomen. (Studia Grammatica 43) Berlin: Akademie-Verlag.

Heusinger, Klaus von (1999). Intonation and Information Structure. Habilitationsschrift, University of Konstanz.

Lenerz, Jürgen (1977). Zur Abfolge nominaler Satzglieder im Deutschen. Tübingen: Narr.

Lenerz, Jürgen (2001.) Word Order Variation: Competition or Co-Operation? In: Müller, Gereon/Sternefeld, Wolfgang (2001) Competition in Syntax. Berlin, New York: Mouton de Gruyter, 249-281.

Meinunger, André (2000). Syntactic Aspects of Topic and Comment. Amsterdam/Philadelphia: John Benjamins.

Rizzi, Luigi (1997). The fine structure of the left periphery. In: Haegemann, Liliane (1997) Elements of grammar: handbook in generative syntax. Dordrecht: Kluwer, 281-337. 